
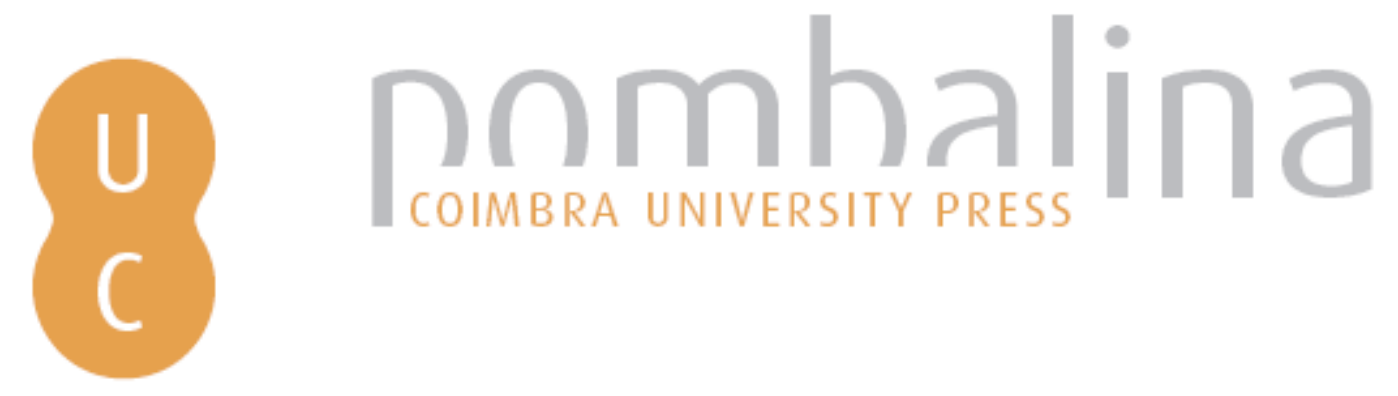

\title{
Energy efficiency governance in the Europe an Union Member States: analysis on current status
}

\author{
Autor(es): $\quad$ Pereira, Guillermo Ivan; Silva, Patrícia Pereira da \\ Publicado por: Imprensa da Universidade de Coimbra \\ URL \\ persistente: URI:http://hdl.handle.net/10316.2/38150 \\ DOI: $\quad$ DOl:http://dx.doi.org/10.14195/978-989-26-1039-9_4 \\ Accessed : $\quad$ 26-Apr-2023 16:27:25
}

A navegação consulta e descarregamento dos títulos inseridos nas Bibliotecas Digitais UC Digitalis, UC Pombalina e UC Impactum, pressupõem a aceitação plena e sem reservas dos Termos e Condições de Uso destas Bibliotecas Digitais, disponíveis em https://digitalis.uc.pt/pt-pt/termos.

Conforme exposto nos referidos Termos e Condições de Uso, o descarregamento de títulos de acesso restrito requer uma licença válida de autorização devendo o utilizador aceder ao(s) documento(s) a partir de um endereço de IP da instituição detentora da supramencionada licença.

Ao utilizador é apenas permitido o descarregamento para uso pessoal, pelo que o emprego do(s) título(s) descarregado(s) para outro fim, designadamente comercial, carece de autorização do respetivo autor ou editor da obra.

Na medida em que todas as obras da UC Digitalis se encontram protegidas pelo Código do Direito de Autor e Direitos Conexos e demais legislação aplicável, toda a cópia, parcial ou total, deste documento, nos casos em que é legalmente admitida, deverá conter ou fazer-se acompanhar por este aviso.

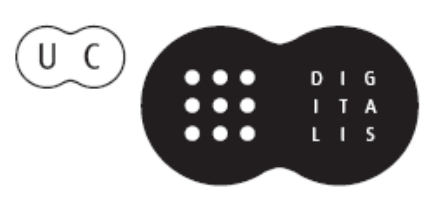


IMPRENSA DA UNIVERSIDADE DE COIMBRA

COIMBRA UNIVERSITY PRESS

\section{ASSESSMENT \\ METHODOLOGIES}

ENERGY, MOBILITY AND OTHER

REAL WORLD APPLICATION

\section{PEDRO GODINHO \\ JOANA DIAS}

EDITORS

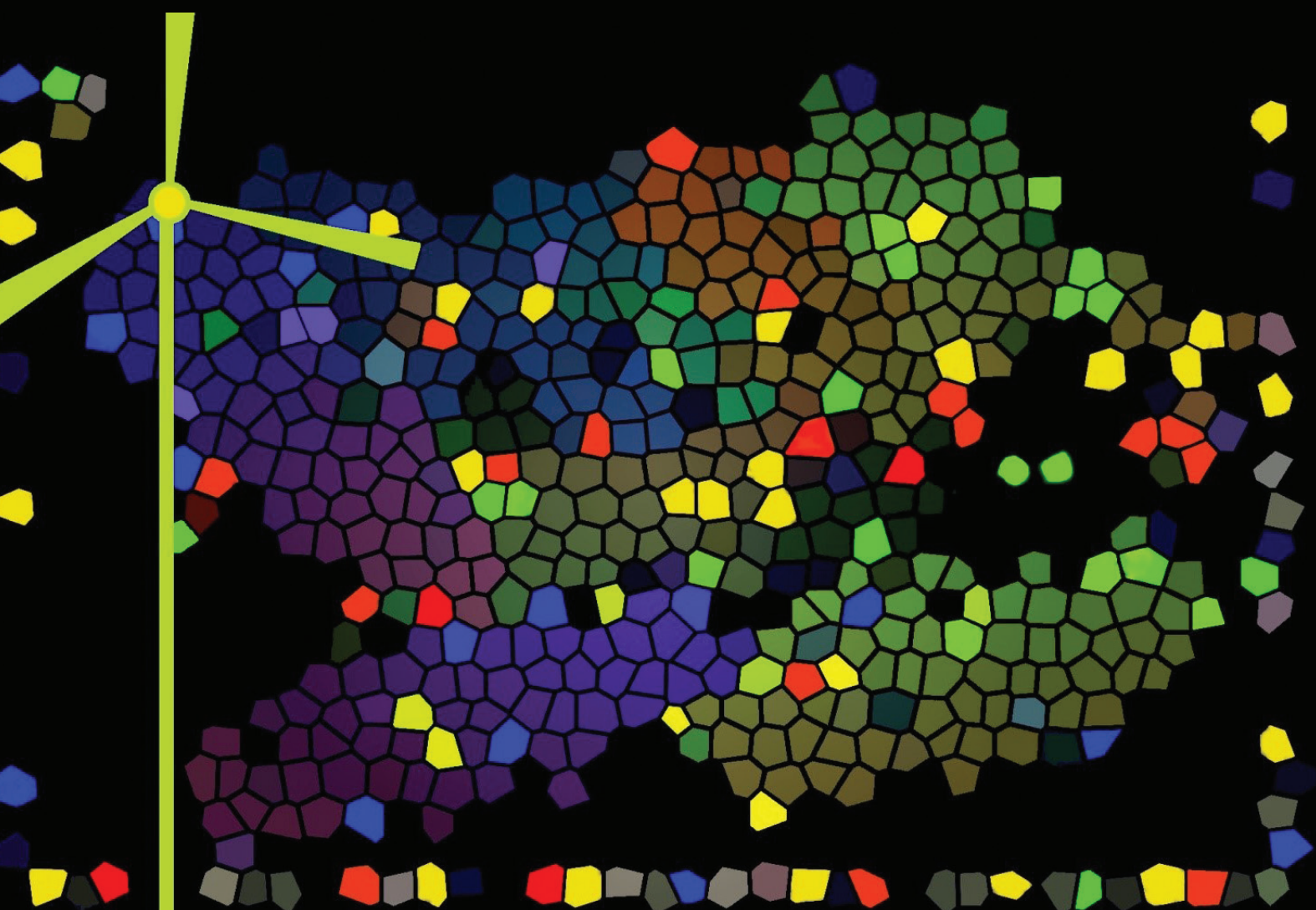




\title{
ENERGY EFFICIENCY GOVERNANCE IN THE EUROPEAN UNION MEMBER STATES - ANALYSIS ON CURRENT STATUS
}

\author{
Guillermo Ivan Pereira ${ }^{1,3}$ and Patrícia Pereira da Silva ${ }^{1,2,3}$
}

\begin{abstract}
Improving energy efficiency in the European Union is a complex task, which requires the commitment of Member States to be accomplished. The existing $20 \%$ energy efficiency target for 2020, recently reinforced for 2030 towards a $27 \%$ energy consumption reduction goal creates a higher pressure to deliver the potential benefits for the economy, environment and society. This research paper presents a governance analysis, as a proxy on the ability of Member States to contribute to the existing energy efficiency targets. The governance analysis conducted for the EU-28 highlights that more efforts are required to ensure that Member States follow and adopt existing legislation, alongside with developments on the existing financial support mechanisms, human capacities and institutional structures. Furthermore, individual country analysis depicts a misalignment on the governance performance for the EU-28 Member States.
\end{abstract}

Keywords: Energy Efficiency, European Union, Governance, Energy Policy.

\footnotetext{
${ }^{1}$ Energy for Sustainability Initiative - MIT Portugal Program - University of Coimbra

2 Faculty of Economics - University of Coimbra

3 INESC Coimbra - Institute for Systems Engineering and Computers at Coimbra

e-mail: gpereira@student.dem.uc.pt,patsilva@fe.uc.pt
} 


\section{Introduction}

Creating stimuli towards a more energy efficient European Union (EU) has been a key pillar in the existing policy agendas. Member States have been called to collaborate further on this effort through the latest Energy Efficiency Directive (EED) released in 2012 (European Parliament, 2012b) to ensure the achievement of the proposed energy efficiency (EE) targets by 2020 , of $20 \%$ reduction of primary energy consumption set on the EU 2020 goals (European Commission, 2011b). Implementing actions that contribute to greater $\mathrm{EE}$ in the EU is crucial.

Whilst the EU strives to follow the plan for energy and climate for 2020, the European Commission (EC) has already defined the pipeline beyond 2020 and towards 2030. In this new policy framework the EE ambitions are greater, the EE communication released in 2014 (European Commission, 2014d) proposed a target for increasing EE by $27 \%$ in 2030 . This evolution is backed by a set of governance guidelines that are designed to ensure the effective implementation of plans and Member States collaboration to achieve this target. It is worth noting that of the proposed energy and climate targets for 2020, only the one related to EE was at risk of not being achieved, the realistic adjusted potential identified by the EC (European Commission, 2014c) stood at 17\%, which represented a positive evolution from previous estimations in 2009 that pointed at the possibility of only reaching $9 \%$ of energy consumption reduction instead of the 20\% goal defined (European Commission, 2011a). These figures present a positive evolution towards the policy targets. However a small gap on EE represents a risk that has to be mitigated.

The aim of this paper is to present an EE governance analysis based on a framework proposed by Jollands \& Ellis, (2009a), as well as to provide information on individual Member States EE governance performance. This research is designed to provide insightful indications on current strengths and weaknesses of EE governance in the EU, which are important from a policy makers' perspective when designing, developing or evaluating policy agendas and possible targets for future implementation. The organisation of the paper is as follows. Section 2, presents and 
discusses the concepts of governance and its application on the EE field, as well as EU-wide actions, Section 3, presents the selected indicators and analysis methods, Section 4, unveils the results of the governance analysis and Member States performance, and Section 5 concludes and presents pathways for future work.

\section{Energy efficiency governance}

The concept of governance applied to EE was presented by the International Energy Agency (IEA, 2010) as well as by Jollands \& Ellis (2009a, 2009b), and associated with the use of political influence, organisations and resources by decision making agents to deliver greater EE. This concept can be easily understood when looking at the EE policy context in the EU, which engages EU-wide institutions, Member States Governments, citizens and private sector players into a set of strategies and roadmaps towards enhanced EE. To do so the EU implements strategies and directives at different levels in order to create the required motivation to deliver the planned targets.

\subsection{EE actions in the $E U$}

The different levels of EE actions in the EU are part of an interconnected governance framework which aims at ensuring the necessary mechanisms for delivering the energy and climate related targets.

\subsubsection{Strategic level}

At strategic level the EU has been implementing a range of policy roadmaps and communications that create a framework for action, and enable new directives and regulations as well as support actions to be designed as supporting mechanisms for these strategies. Table 1, below, presents the existing pipeline of strategic orientations from 2020 until 2050 for climate and energy. 
Table 1: Strategic level action of EE EU governance adapted from (Pereira, 2014).

\begin{tabular}{|c|c|c|}
\hline $\begin{array}{c}\text { Strategic } \\
\text { level action }\end{array}$ & Main goals /Ambitions & References \\
\hline $\begin{array}{l}\text { Europe } 2020 \\
20-20-20\end{array}$ & $\begin{array}{l}20 \% \text { reduction of primary energy consumption; } \\
20 \% \text { increase in renewable energy; } \\
20 \% \text { reduction of GHG emissions. }\end{array}$ & $\begin{array}{l}\text { (European Commission, } \\
\text { 2010, 2011b; European } \\
\text { Parliament, 2012a) }\end{array}$ \\
\hline $\begin{array}{l}2030 \text { frame- } \\
\text { work for } \\
\text { climate and } \\
\text { energy poli- } \\
\text { cies }\end{array}$ & $\begin{array}{l}\text { This action sets the standards to build the } 2030 \mathrm{Eu}- \\
\text { ropean strategy for energy and climate, taking into } \\
\text { account the learning points from Europe } 2020 \text { 20-20- } \\
20 \text { and the Europe } 2050 \text { Roadmap; } \\
40 \% \text { reduction of GHG emissions: } \\
27 \% \text { increase in renewable energy; } \\
27 \% \text { reduction of primary energy consumption. }\end{array}$ & $\begin{array}{l}\text { (European Commission, } \\
\text { 2013a, 2013b, 2014a) }\end{array}$ \\
\hline $\begin{array}{l}\text { Europe } 2050 \\
\text { Roadmap }\end{array}$ & $\begin{array}{l}\text { A secure, competitive and decarbonised energy sys- } \\
\text { tem; } \\
80-95 \% \text { reduction of GHG emissions (indicative). }\end{array}$ & $\begin{array}{l}\text { (European Commission, } \\
\text { 2011c; European Parlia- } \\
\text { ment, 2013; Faber et al., } \\
\text { 2012) }\end{array}$ \\
\hline
\end{tabular}

The strategic level actions in Table 1, serve as guidelines for what should be achieved in the future in terms of climate and energy goals within 5 (i.e.: in 2020), 15 (i.e.: in 2030) and 35 (i.e.: in 2050) years. These high-level strategies enable the creation of laws that enforce actions and the implementation of policies in a defined timeframe and consistent with a set of requirements.

\subsubsection{Legislative level}

In terms of the laws created, the EED is the key legislative instrument, enacted in 2012 which is far more ambitious, when compared to the previous Energy Services Directive (European Parliament, 2006). The new instrument goes beyond energy services and end-uses, including actions concerning the $\mathrm{EE}$ in the generation, transmission and distribution of energy in the EU. The key measures implemented by this Directive are further described by the European Commission (2011d, 2011e), and include measures for the public sector, residential consumers, Small and Medium Enterprises (SMEs) and energy sales companies.

The legislative actions at the EU level go beyond the EED, which is an overarching instrument that incorporates other EU level laws. A more detailed analysis of the existing legislations can be found in Pereira (2014). Additionally to the legislative and strategic actions mentioned 
the EU develops a range actions that support specific parts of the policy roadmaps.

\subsubsection{Support level}

Support actions for EE represent efforts to remove market barriers and support the delivery of planned energy savings. These actions are designed to boost information sharing, training activities and financial support enabling a broader reach of the necessary evolution on practices and technologies across the EU that contribute to improvements on EE. An example of this support actions is the EU ENERGY STAR Programme, for labelling energy efficient office equipment, based on an agreement between the USA government and the EU (European Commission, 2013a).

These initiatives consist on actions that beyond their direct contribution to EE development, represent measures to improve energy security and environmental quality, such as Carbon dioxide $\left(\mathrm{CO}_{2}\right)$ emissions decrease and renewable energy sources (RES) integration and deployment.

\subsection{Governance analysis methodology}

The framework designed by the EU in terms of EE actions defines a set of measurable indicators to understand the level of compliance form Member States level in regards to EU-wide actions. These, in combination with other governance dimensions, will be used to conduct an analysis on the current status of governance of EE in the EU. The methodology that the authors will follow was developed by Jollands \& Ellis (2009b), to enable the assessment of the level of compliance in different governance areas and at different levels (i.e.: local, national, international). The authors of the methodology defined the foundations for governance, as the necessary resources required to establish a governance system, consisting of: (i) institutional structures, (ii) human and financial resources, (iii) human capacity and (iv) political support. These dimensions provide the direction on the analysis to be performed in the following section. 
Jollands \& Ellis (2009b), represent their methodology through a radial chart as presented in the following diagram (Figure 1).

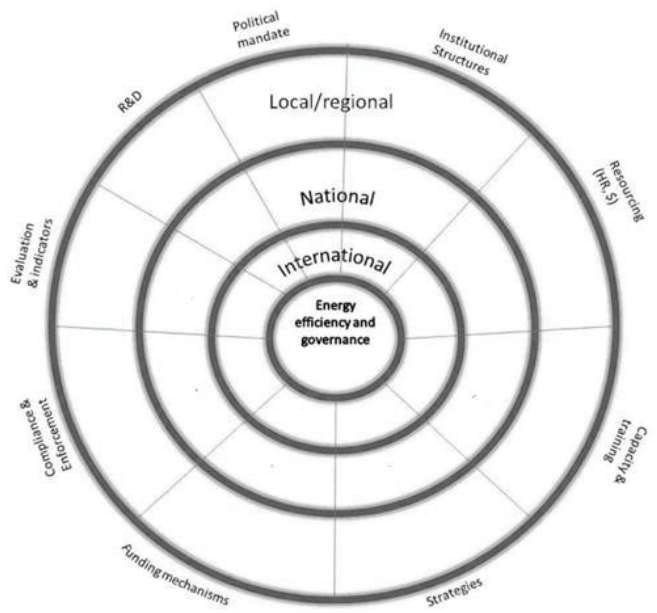

Figure 1: Schematic of governance dimensions. Adapted from Jollands \& Ellis (2009b)

The governance analysis to be presented for the EU Member States is based on an adaptation of the above presented methodology to be able to aggregate relevant indicators into an analysis that provides relevant outputs on the status of EE governance in the EU. The level of the analysis is international (i.e.: EU-wide), as indicators form the 28 Member States will be selected, collected and analysed. The following section presents the main analysis conducted for the selected dimensions within the defined framework. The analysis consists on an update and improvement of the governance analysis presented in Pereira (2014).

\section{Data collection and analysis}

The data gathered for the analysis is based on the World Energy Council Database for Energy Efficiency (World Energy Council, 2015), and publications released by the EC (European Commission, 2014d, 2015). The EE governance indicators collected enable the development of an analysis 
covering the four foundation dimensions of governance presented by Jollands \& Ellis (2009b). The following table aggregates the indicators included within each dimension for analysis.

Table 2: EE governance indicators collected and analysed.

\begin{tabular}{|l|l|}
\hline Dimension & \multicolumn{1}{|c|}{ Indicator } \\
\hline \multirow{3}{*}{$\begin{array}{l}\text { Institutional } \\
\text { Structures }\end{array}$} & National energy agency \\
\cline { 2 - 3 } & Ministry department for EE \\
\cline { 2 - 3 } $\begin{array}{l}\text { Financial } \\
\text { Capacity }\end{array}$ & Local energy agencies \\
\hline \multirow{4}{*}{$\begin{array}{l}\text { Human Ca- } \\
\text { pacity }\end{array}$} & Dedicated EE funds \\
\cline { 2 - 3 } & Ministry department for EE \\
\cline { 2 - 3 } & Local energy agencies \\
\hline \multirow{5}{*}{$\begin{array}{l}\text { Political Sup- } \\
\text { port }\end{array}$} & National EE programmes with targets \\
\cline { 2 - 3 } & Energy law with EE targets \\
\cline { 2 - 3 } & Dedicated EE law \\
\cline { 2 - 3 } & EPBD Transposition (on 22/07/2014), due 09/07/2012 \\
\cline { 2 - 3 } & EPBD Cost-optimal calculation report (on 22/07/2014), due 21/03/2013 \\
\cline { 2 - 3 } & EED Targets presented (on 16/07/2014), due 30/04/2013 \\
\cline { 2 - 3 } & EED Building renovation strategy (on 16/07/2014), due 30/04/2013 \\
\cline { 2 - 3 } & EED EE obligations/alternative programmes (on 16/07/2014), due 05/12/2013 \\
\cline { 2 - 3 } & $\begin{array}{l}\text { 3rd Round of National EE Action Plans (NEEAPs) delivered (on 16/07/2014), due } \\
\text { 30/04/2013 }\end{array}$ \\
\cline { 2 - 3 } & EED Transposition (on 16/07/2014), due 05/06/2014 \\
\hline
\end{tabular}

The data analysis process presented in this paper is two staged. Firstly, the information obtained is categorized considering the level of compliance with the specific governance indicator being analysed. The analysis of the indicators within the institutional structures, financial capacity and political support dimensions for each Member State are categorized according to the following criteria: $(i)$ Complies with the indicator; $(i i)$ Does not comply with the indicator; (iii) No information available on the indicator; and (iv) Ongoing effort to comply with the indicator.

For the indicators within the Human Capacity/People dimension the categorisation is as follows: ( $i$ ) Human resources allocated; (ii) No human resources allocated; (iii) No information available on the indicator.

The second stage of the governance analysis consists on the development of a global ranking of the 28 Member States, which complements 
the EU-wide analysis presented through the application of the Jollands \& Ellis (2009b) framework on the first stage. The ranking method followed is based on the allocation of points, which are assigned according to the level of compliance attributed on the first stage of the analysis. The points given to obtain the global EE governance ranking of the 28 Member States are presented in the following table (Table 3 ).

Table 3: Governance ranking point assignment method.

\begin{tabular}{|c|c|c|c|}
\hline Ranking Criteria & $\begin{array}{c}\text { Points } \\
\text { assigned }\end{array}$ & Ranking Criteria & $\begin{array}{c}\text { Points } \\
\text { assigned }\end{array}$ \\
\hline \multicolumn{2}{|c|}{$\begin{array}{c}\text { Institutional, Legislative and Financial } \\
\text { Dimensions }\end{array}$} & \multicolumn{2}{|c|}{ Human capacity Dimension } \\
\hline Complies with the indicator; & 1 & Human resources allocated & 1 \\
\hline Does not comply with the indicator; & -1 & No human resources allocated & -1 \\
\hline $\begin{array}{l}\text { No information available on the } \\
\text { indicator; }\end{array}$ & 0 & \multirow[t]{2}{*}{$\begin{array}{l}\text { No information available on the } \\
\text { indicator }\end{array}$} & \multirow[t]{2}{*}{0} \\
\hline $\begin{array}{l}\text { Ongoing effort to comply with the } \\
\text { indicator. }\end{array}$ & 0,5 & & \\
\hline
\end{tabular}

The main findings obtained from the aggregation of the indicator set collected are now presented, providing an overview on the aggregate performance of EU-28 Member State ${ }^{4}$ for the analysed governance dimensions 5 .

\subsection{Institutional structures}

In terms of institutional structures the Energy Agencies at National and Local Level are well implemented throughout the EU. In contrast

\footnotetext{
${ }^{4}$ The results presented include acronyms for each Member State as follows: Austria: AT; Belgium: BE; Bulgaria: BG; Croatia: HR; Cyprus: CY; Czech Republic: CZ; Denmark: DK; Estonia: ET; Finland: FI; France: FR; Germany: DE; Greece: EL; Hungary: HU; Ireland: IE; Italy: IT; Latvia: LV; Lithuania: LT; Luxembourg: LU; Malta: MT; Netherlands: NL; Poland: PL; Portugal: PT; Romania: RO: Slovakia: SK; Slovenia: SI; Spain: ES; Sweden: SE; United Kingdom: UK.

When presenting results "n.a." stands for: no information available.

5 A detailed table in Annex A, presents the Member States included in each group of the analyses presented for the four dimensions analysed through this research.
} 
with this only $53 \%$ of the Member States have a Ministry Department focused on EE issues.

\subsection{Financial capacity}

The financial capacity dimension was analysed by searching for the existence of dedicated EE funding at the Member State level as a positive point to promote and support EE improvements. The financial capacity analysis presents that no specific funding for EE exists in Belgium (BE), Estonia (ET), Greece (EL), Finland (FI), France (FR), Ireland (IE), Luxembourg (LU), Latvia (LV), Malta (MT) and Sweden (SE).

\subsection{Human capacity/People}

The dimension associated with human capacity and people is analysed through the data available on the allocation of human resources in the different types of organisations analysed in the institutional structures dimension.

Human resources allocated to the organizations engaged on promoting EE at national or regional level, through energy agencies, or at governmental level through ministry departments for EE vary widely. Therefore, in order to avoid a misleading analysis the human capacity compliance indicator was organized by categories, as described previously. Through this approach the authors considered that Member States were complying with the governance indicator when any number human resources where allocated to the organisation under analysis.

From the Member states allocation of human resources it is possible to observe a greater work force on EE related institutions by Central Europe and Nordic Countries. For National Energy Agencies, the Netherlands (NL) ranks highest with a total workforce of 1250 people. The case of the Ministry Departments for EE is led by Denmark (DK) with a workforce of 40 people. Sweden (SE) is the Member State with 
more staff allocated to Local Energy Agencies with a workforce of 303 people.

\subsection{Political support}

Regarding political support, the analysis is based on the level of compliance with the latest EU-wide EE related directives, the EED (European Parliament, 2012b) and the Energy Performance in Buildings Directive (EPBD) (European Parliament, 2010).

From the outputs obtained the most critical is the current status of implementation of the EED by Member States, as available data shows that only Cyprus (CY), Denmark (DK), Italy (IT), Malta (MT), and Sweden (SE) have the EE legislative instrument transposed into national legislation, the deadline was due on June, 2014 as outlined in Table 2. However, despite the existing failure to transpose the EED on time all Member States have presented their EE targets to meet by 2020 , as one of the obligations stipulated, as well as have all presented the EE obligations schemes or alternative initiatives to foster the improvement of EE levels.

The outputs herein presented are aggregated and discussed in the following section providing the main results of the research process. The research framework for EE governance analysis obtainable in Figure 1 is presented in an adapted version according to the governance dimensions and indicators outlined in Table 2. In addition the Member States EE governance ranking is disclosed, providing a basis to better understand the regions in the EU where more effort is necessary to ensure the necessary contribution to achieve the set EE targets for 2020, which will dictate the potential to achieve the more ambitious targets towards 2030, of $27 \%$ on EE.

\section{Results and Discussion}

Understanding the status of EE governance in the EU is an underpinning issue considering the existing climate and energy policies, which 
are based on ambitious energy consumption reduction targets. The two stage analysis developed is beneficial in terms of the insights it provides at different levels, informing policy and decision makers.

The first stage of the analysis, based on the application of the governance framework of Jollands \& Ellis (2009b) adapted to the available indicators, provides EU-wide information on the current status of the analysed dimensions. This is relevant to provide policy makers with the areas where more action is needed, or to enable ex-post analyses of the implemented laws, programmes and support initiatives to be promoted.

The second stage of the research based on the application of a method to rank Member States according to their EE governance performance (see Table 3 for ranking method) that provides complementary information. From the results obtained policy markers' can access a strengthened perspective on the status of EE governance in each Member State, this enables the design of EE actions that target particular challenges. In addition the ranking enables Member States to have a clear view of their positioning in the EU-wide framework. Beyond the information it provides to a Member State regarding their own situation, it is also a tool to assist the identification of best case practices, as those with a lower performance can analyse the governance practices of better ranked countries in search of successful actions and programmes. The result of these processes is presented below.

\subsection{Governance analysis framework results}

The governance analysis framework provides a global overview on all the indicators analysed, presented through the following graph (Graph 1).

The results (Graph 1) are presented in terms of number of Member States of the EU-28 that are complying with the governance indicator in each dimension (e.g.: In the financial capacity dimension, for the dedicated EE funds 18 Member States have a dedicated fund, therefore comply with the indicator). 
In terms of institutional structure and human capacity the EU presents a significant potential for improvements. Despite the existing structures the results show that only $82 \%$ of the Member States have National Energy Agencies, 53\% have Ministry Departments for EE. Local Energy Agencies present the best outcome with $92 \%$ Member States complying with the indicator. This analysis of the existing structures reflects a similar situation in the human capacity dimension as the data for human resources allocated to EE organizations is for the same institutions analysed in the institutional structures dimension.

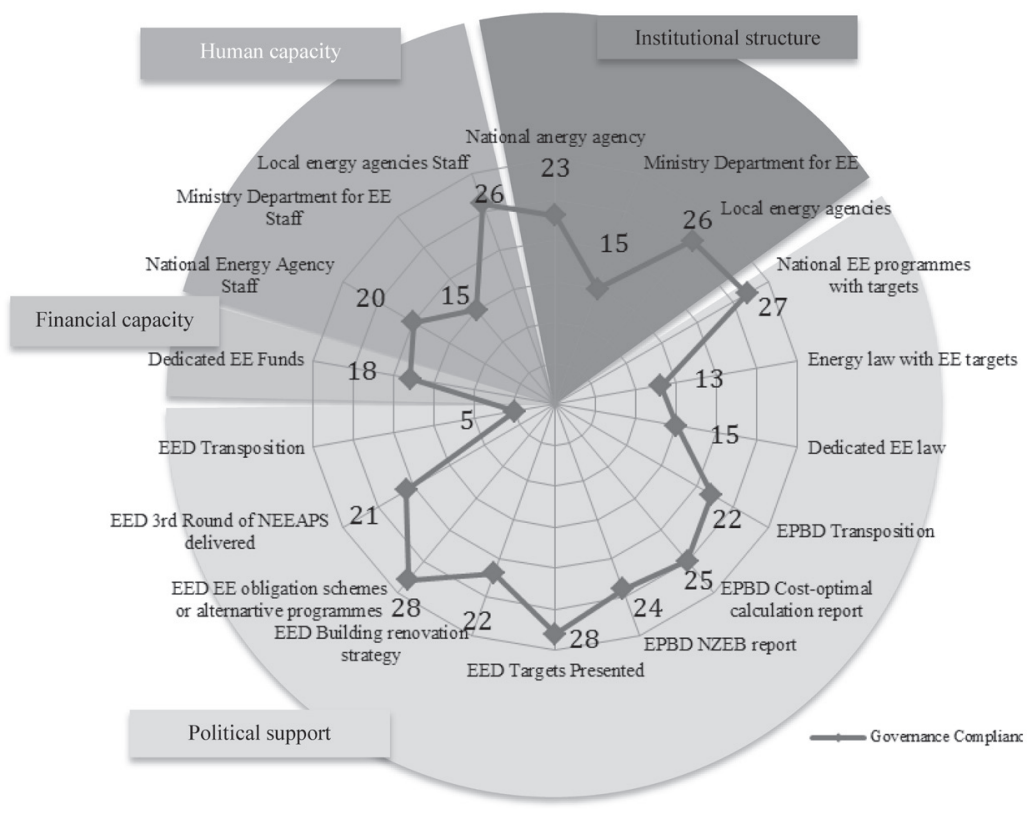

Graph 1: EU governance analysis.

In terms of financial capacity $64 \%$ of the EU has dedicated EE financing schemes, which are either funded through the national public budget, through specific taxes for climate and energy related action programmes.

The political support dimension presents positive results associated with the EPBD transposition, with $79 \%$ of the Member States with the directive transposed into their national law. However, the situation associated with the EED is significantly weaker, with only $18 \%$ of the Member 
States with the directive transposed. Considering that the transposition was due on June, 2014 and the data used for the analysis is from July, 2014 date by which the majority of the Member States failed to comply with the target date. The EED was designed to increase EU-wide efforts towards a more energy efficient EU, the failure to adopt the measures proposed will have a direct impact on the ability to deliver the planned goals, as well as on ensuring a wide-ranging collaborative effort for a more efficient use of energy resources.

From the indicator set collected the area of political support dimension provides a wider vision given a greater availability of information. Further indicators should be analysed in future work in terms of financial capacity, possibly looking for Research and Development related funding at each Member States developed through national funding programmes. For the human capacity dimension the analysis should evolve to include governance indicators related to available skills at each Member State in the area of EE. The institutional structure dimension herein presented was based on support structures; the governance analysis can be complemented by including indicators from the private sector (e.g.: indicators on the number of companies working in the field of EE).

To ensure that governance can be evaluated over time, allowing the identification of improvements and declines on governance performance, a set of common EU-wide indicators should be developed and collected over time providing periodic insights from the Member State level and from the EU overall situation.

The EC (European Commission, 2014b) is aware of the need of a stronger governance framework and as part of the 2030 energy and climate agenda has presented the ambition to improve the EE governance process existing in the 2020 energy and climate framework, towards a more consolidated and supportive system. Through this the EC envisions to: $(i)$ deliver the EU energy and climate agenda goals (ii) improve Member States' approaches to EU policies implementation; (iii) stimulate the competition and integration of energy markets and (iv) reduce the uncertainties related to the set targets to drive more investment. The proposed governance framework improvement 
is supported by a three-step process (European Commission, 2014b), as presented in Figure 2.

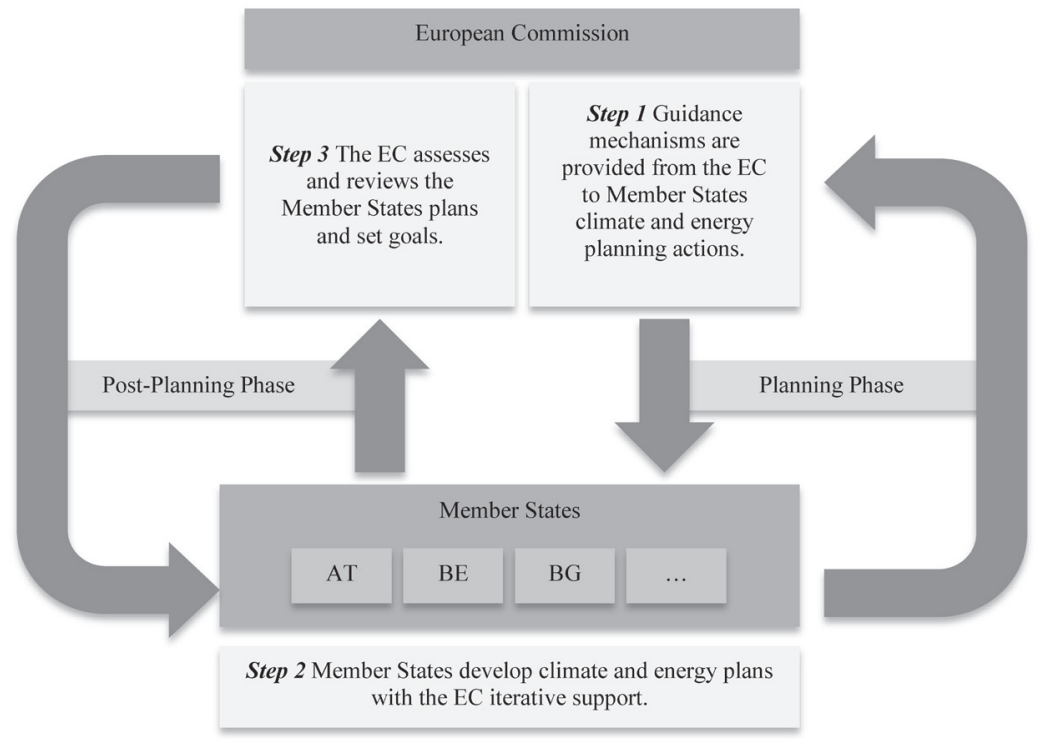

Figure 2: Governance improvement methodology, adapted from (European Commission, 2014b).

The main feature of the proposed improvement methodology (Figure 2 ) is the overarching nature of the process covering the whole planning phase and providing further support in the post-planning period, ensuring the adequacy and attainability of the developed plans.

\subsection{Member States governance performance ranking results}

The development of a governance performance ranking was based on the goal to map the best performing Member States, according to the selected governance analysis criteria, whilst providing also information on Member States where stronger efforts have to be implemented to ensure a good level of EE governance.

To allow some comparison three different levels where created to aggregate the Member States into larger groups. From the raking method 
presented (see Table 3) and considering the governance criteria used for analysis any Member State can score a maximum of 18 points (i.e.: when complying with all the indicators), and a minimum of -18 points (i.e.: when failing to comply with all the indicators. The intervals used to group the Member States and a brief description of the categories is presented on the table below (Table 4). The definition of the categories proposed hereafter is based on the aim to classify Member States, according to three categories: $1^{\text {st }}$ League, $2^{\text {nd }}$ League and $3^{\text {rd }}$ League in terms of EE governance performance. The performance point intervals established for each category were defined to enable the identification of a small group of top performing Member States (i.e.: $1^{\text {st }}$ League), which corresponds to high levels of compliance with the EE governance indicators assessed in this analysis. The second category (i.e.: $2^{\text {nd }}$ League) enables the identification of Member States with an average performance, which could benefit from best case practices from Member States included in the $1^{\text {st }}$ League Member States group, whilst the third category (i.e.: $3^{\text {rd }}$ League) aggregates all the Member States with low performance on EE governance. The authors propose point assignment interval thresholds that expand through the defined categories from a very limited $1^{\text {st }}$ League category, from 15 to 18 points; to a more extended $2^{\text {nd }}$ League, from 6 to 14 points; and a broader $3^{\text {rd }}$ League, from - 18 to 5 points. Defining the point intervals through this method enables the creation of meaningful insights regarding the identification of governance practices among EU Member States, serving as guidance for policy makers. From the authors' point of view, this approach adds more value to the presented analysis than the definition of performance point intervals following the definition of equal ranges across the possible scores to be obtained by Member States. 
Table 4: Ranking Categories.

\begin{tabular}{|c|c|l|}
\hline Category & Performance Point Interval & \multicolumn{1}{c|}{ Brief description } \\
\hline $1^{\text {st }}$ League & $>14$ points & $\begin{array}{l}\text { Top performing Member States, contributing to the } \\
\text { EE development and serving as potential sources of } \\
\text { best case practices. }\end{array}$ \\
\hline $2^{\text {nd }}$ League & $<=14$ and $>5$ points & $\begin{array}{l}\text { Member States with a medium-low governance per- } \\
\text { formance. }\end{array}$ \\
\hline $3^{\text {rd }}$ League & $<=5$ points & $\begin{array}{l}\text { Member States with a low performance, which can } \\
\text { benefit from best case practices observed in } 1^{\text {st }} \\
\text { League Member States. }\end{array}$ \\
\hline
\end{tabular}

The point assignment process enabled the development of the overall Member States ranking. It is important to note that the point assignment process and final results are based on the available information at the time of development of this research. Some Member States performance may be depicted better or worse than it is in reality, given the impossibility to access the necessary data to point a particular indicator. Despite the effort of the authors that based the data collection process in reliable databases, some information was not available. This barrier encountered in the data collection analysis serves also as a suggestion for Member States and the EC to communicate this data and other of similar nature in a more organised manner, reducing the information access barrier. The following graph (Graph 2) presents the outputs of the performance analysis.

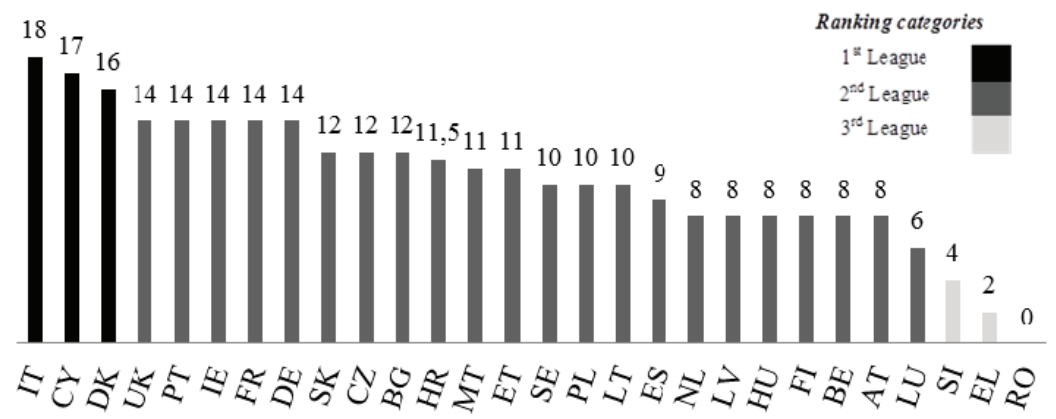

Graph 2: EU Member States performance analysis.

Considering the categories defined Italy (IT) is at the forefront of governance performance complying with all the analysed dimensions 
ranking in number one on the $1^{\text {st }}$ League group followed by Cyprus (CY) and Denmark (DK). The group representing the $2^{\text {nd }}$ League has as best performers Germany (DE), France (FR), Ireland (IE), Portugal (PT) and the United Kingdom (UK). The $3^{\text {rd }}$ league is composed by Slovenia (SI), Greece (EL) and Romania (RO), all of which fail to comply with a significant number of the governance performance indicators selected. The results obtained indicate significant discrepancies throughout the EU in terms of governance. This analysis further validates the need to implement the governance improvement framework presented in Figure 2, to align the Member States governance levels to a highly-collaborative standard based on timely implementation of policies and effective national plans for EE.

\section{Conclusion}

The research conducted on the current status of EE governance is crucial considering the proximity to the 2020 deadline to deliver a $20 \%$ energy consumption reduction in the EU. This analysis gains greater relevance considering the already presented goals towards 2030 of $27 \%$ EE increase, with an ambition to raise the goal to $30 \%$. Considering these set targets, the need of an aligned effort to govern and foster EE is well justified.

In line with this need for an aligned and collaborative environment towards reducing energy consumption, a first analysis was conducted applying a governance analysis model presented by Jollands \& Ellis (2009b). From the dimensions analysed, the political support is the main source of concerns. Member States are failing to comply with the transposition of EU Directives, designed to drive impetus towards higher levels of EE. The EED as the EU framework legislation that embraces the energy system from generation to end-use on pursuing energy savings has only been implemented by $18 \%$ of the Member States, in contrast with $79 \%$ for the EPBD.

The financial resources dimension has also potential for improvement considering that from this research only $64 \%$ of the Member States have 
dedicated EE funding instruments. Shifting towards an energy efficient EU requires political, social and financial stimulus in order to enable the market for EE to expand and reach a good level of development. Regarding the institutional structures and human capacity the analysis performed was based on public entities and agencies, these indicators present the existence of a good network of National and Local energy Agencies, and fewer Ministry Departments for EE.

These EU-wide governance status results provide the necessary information to structure strategic plans that tackle the identified gaps through different policies, potentially through support actions.

The complementary Member States governance performance ranking (see Graph 2) provided country specific information, which demonstrated a misalignment between the 28 Member States. For instance, through the set of selected indicators and available data, Italy (IT) was able to comply with all governance indicators whilst Romania (RO) failed in most of the dimensions, ranking last on the list. This information has to be taken into consideration when devising national, regional and EU-wide strategies, funding programmes and EE targets, to ensure that these are realistic and match the Member States ability to contribute. The combination of the two analyses conducted should be considered when implementing the governance improvement methodology proposed by the EC (see Figure 2). The analysis was based on publicly available information on the governance indicators selected. The results and Member State ranking are based on this data. To the best knowledge of the authors no database is yet available for the analysis of EE governance, the aggregation of this information on a single source would support better analysis and more robust recommendations.

Future work can include analysis of the interrelations, between the various governance dimensions (e.g.: the impact of the institutional structure on the timely transposition of directives). The analysis of these interlinks will contribute further to prioritising and informing decision makers on where to act, in order to trigger greater levels of EE. Furthermore the analysis herein disclosed shows the EU-wide situation and Member States performance, complementary works can focus on Member States 
individually to understand the regional priorities to foster EE, for this application the indicators must be adapted accordingly to yield relevant results.

Acknowledgments: The first author would like to acknowledge Fundação para a Ciência e Tecnologia (FCT) for supporting this work through the Doctoral Grant PD/BD/105841/2014, awarded on the framework of the MIT Portugal Program funded through the POPH/FSE. The authors would like to acknowledge that this work has been partially supported by the Fundação para a Ciência e a Tecnologia (FCT) under project grant UID/MULTI/00308/2013, and the Energy for Sustainability Initiative of the University of Coimbra.

\section{References}

EUROPEAN COMMISSION, Europe 2020 . A strategy for smart, sustainable and inclusive growth. - $\operatorname{COM}(2010) 2020$ final. Brussels, 2010.

EUROPEAN COMMISSION, Background on energy in Europe. Brussels, 2011a.

EUROPEAN COMMISSION, Energy 2020 - A strategy for competitive, sustainable and secure energy. Brussels. 2011b.

EUROPEAN COMMISSION, Energy Roadmap 2050 - COM(2011) 885/2. Brussels, 2011c.

EUROPEAN COMMISSION, Press Release - 22 June 2011 - Strong impetus to energy savings and energy efficiency. Brussels, 2011d.

EUROPEAN COMMISSION, The Commission' $s$ new Energy Efficiency Directive MEMO/11/440 - 22 June 2011 (pp. 1-6). Brussels, 2011e.

EUROPEAN COMMISSION, European Comission Energy Star Programme. Retrieved November 20, 2013 from http://www.eu-energystar.org/en/en_016.shtml, 2013a.

EUROPEAN COMMISSION, GREEN PAPER - A 2030 framework for climate and energy policies - COM(2013) 169 final. Brussels, 2013b.

EUROPEAN PARLIAMENT, Report on the Energy roadmap 2050, a future with energy (2012/2103(INI)) Committee on Industry, Research and Energy. Brussels, 2013.

EUROPEAN PARLIAMENT,. Directive 2006/32/EC of the European Parliament and the Council of the European Union of 5 April 2006 (2006). European Union: Official Journal of the European Union.

EUROPEAN PARLIAMENT, Directive 2010/31/EU of the European Parliament and of the Council of 19 May 2010 on the energy performance of buildings (recast), Pub. L. No. OJ L 153 (2010). Official Journal of the European Union.

EUROPEAN PARLIAMENT, Delivering on the Europe 2020 Strategy - Handbook for Local and Regional Authorities. Brussels, 2012a.

EUROPEAN PARLIAMENT, Directive 2012/27/EU of the European Parliament and of the Council of 25 October 2012 on energy efficiency, amending Directives 2009/125/EC and 2010/30/EU and repealing Directives 2004/8/EC and 2006/32/EC, Pub. L. No. Volume 
5514 November 2012 (2012). European Union: Official Journal of the European Union, 2012b.

EUROPEAN COMMISSION. 2030 climate and energy goals for a competitive, secure and low-carbon EU economy, IP/14/54. Brussels, 2014a.

EUROPEAN COMMISSION, A policy framework for climate and energy in the period from 2020 to 2030, $\operatorname{COM(2014)~} 15$ Final. Brussels, 2014b.

EUROPEAN COMMISSION, Climate and energy priorities for Europe: the way forward. Brussels, 2014c.

EUROPEAN COMMISSION, Energy Efficiency and its contribution to energy security and the 2030 Framework for climate and energy policy, Annexes 1 of 3, $\operatorname{COM}(2014) 520$ final. Brussels, 2014d.

EUROPEAN COMMISSION, Energy Efficiency Directive Target Reporting. Retrieved January 15, 2015 from http://ec.europa.eu/energy/efficiency/eed/eed_en.htm

FABER, J., SCHROTEN, A., BIES, M., SEVENSTER, M., MARKOSWKA, A., SMIT, M., RIET, J. (2012). Behavioural Climate Change Mitigation Options and Their Appropriate Inclusion in Quantitative Longer Term Policy Scenarios. Delft, April 2012.IEA, Energy Efficiency Governance - Handbook - Second Edition. Paris, 2010. Retrieved December 12, 2014 from http://www.iea.org/publications/freepublications/publication/name,3931,en.html

JOLLANDS, N., \& ELLIS, M., Energy efficiency governance - an emerging priority - ECEEE Summer Studies 2009, 91-100, 2009a. Retrieved December 11, 2014 from http://www. eceee.org/library/conference_proceedings/eceee_Summer_Studies/2009/Panel_1/1.086/ paper

JOLLANDS, N., \& ELLIS, M., Energy efficiency governance - an emerging priority - ECEEE Summer Studies 2009. In N. Jollands \& M. Ellis (Eds.), . European Council for an Energy Efficient Economy, 2009b. Retrieved December 10, 2014 from http://www.eceee.org/ library/conference_proceedings/eceee_Summer_Studies/2009/Panel_1/1.086/presentation

PEREIRA, G. I. (2014). Connecting energy efficiency progress and job creation potential, Master Degree Dissertation, University of Coimbra, Coimbra, Portugal.

WORLD ENERGY COUNCIL. (2015). Energy Efficiency Policies and Measures Database. Retrieved January 28, 2015, from http://www.wec-indicators.enerdata.eu/world.php 
ANNEX A

\begin{tabular}{|c|c|c|c|c|}
\hline \multirow[b]{2}{*}{$\begin{array}{c}\text { Governance } \\
\text { analys is } \\
\text { framework }\end{array}$} & FinancialCapacity & \multicolumn{3}{|c|}{ Human Capacity/Poeple } \\
\hline & Dedicated EE F unds & $\begin{array}{c}\text { National } \\
\text { Energy } \\
\text { Agency Staff } \\
\end{array}$ & $\begin{array}{c}\text { Minis try } \\
\text { Department } \\
\text { forEE Staff }\end{array}$ & $\begin{array}{l}\text { Localenergy } \\
\text { agencies Staff }\end{array}$ \\
\hline Country & $\begin{array}{l}\text { Status 1: Yes; } 2 \text { :No; } \\
\text { 3:n.a. }\end{array}$ & Staff count & Staff count & Staff count \\
\hline AT & & 74 & n.a. & 12 \\
\hline $\mathrm{BE}$ & 2 & n.a. & 6 & 19 \\
\hline BG & & 70 & n.a. & 6 \\
\hline CY & & n.a. & 40 & 2 \\
\hline $\mathrm{CZ}$ & & n.a. & 10 & 44 \\
\hline DE & & 100 & 10 & 59 \\
\hline DK & & 41 & 40 & 12 \\
\hline $\mathrm{EE}$ & 2 & n.a. & 3 & 1 \\
\hline EL & 2 & 150 & n.a. & 10 \\
\hline ES & & 141 & 0 & 42 \\
\hline FI & 2 & 33 & 5 & 7 \\
\hline FR & 2 & 1006 & 15 & 57 \\
\hline HR & & 100 & n.a. & 6 \\
\hline $\mathrm{HU}$ & & 60 & n.a. & 151 \\
\hline $\mathbb{E}$ & 2 & 43 & 6 & 16 \\
\hline IT & & 150 & 10 & 41 \\
\hline LT & & 29 & n.a. & 1 \\
\hline LU & 2 & 8 & n.a. & 1 \\
\hline LV & 2 & n.a. & n.a. & 3 \\
\hline MT & 2 & 49 & 4 & n.a. \\
\hline NL & 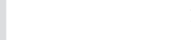 & 1250 & 0 & 4 \\
\hline PL & & 26 & 4 & 10 \\
\hline $\mathrm{PT}$ & 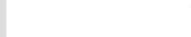 & 40 & 10 & 23 \\
\hline RO & 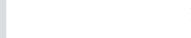 & n.a. & 0 & n.a. \\
\hline SE & 2 & 35 & 0 & 303 \\
\hline SI & 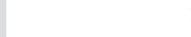 & n.a. & 6 & 6 \\
\hline SK & 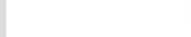 & 118 & 0 & 5 \\
\hline UK & ( & n.a. & 1600 & 34 \\
\hline
\end{tabular}




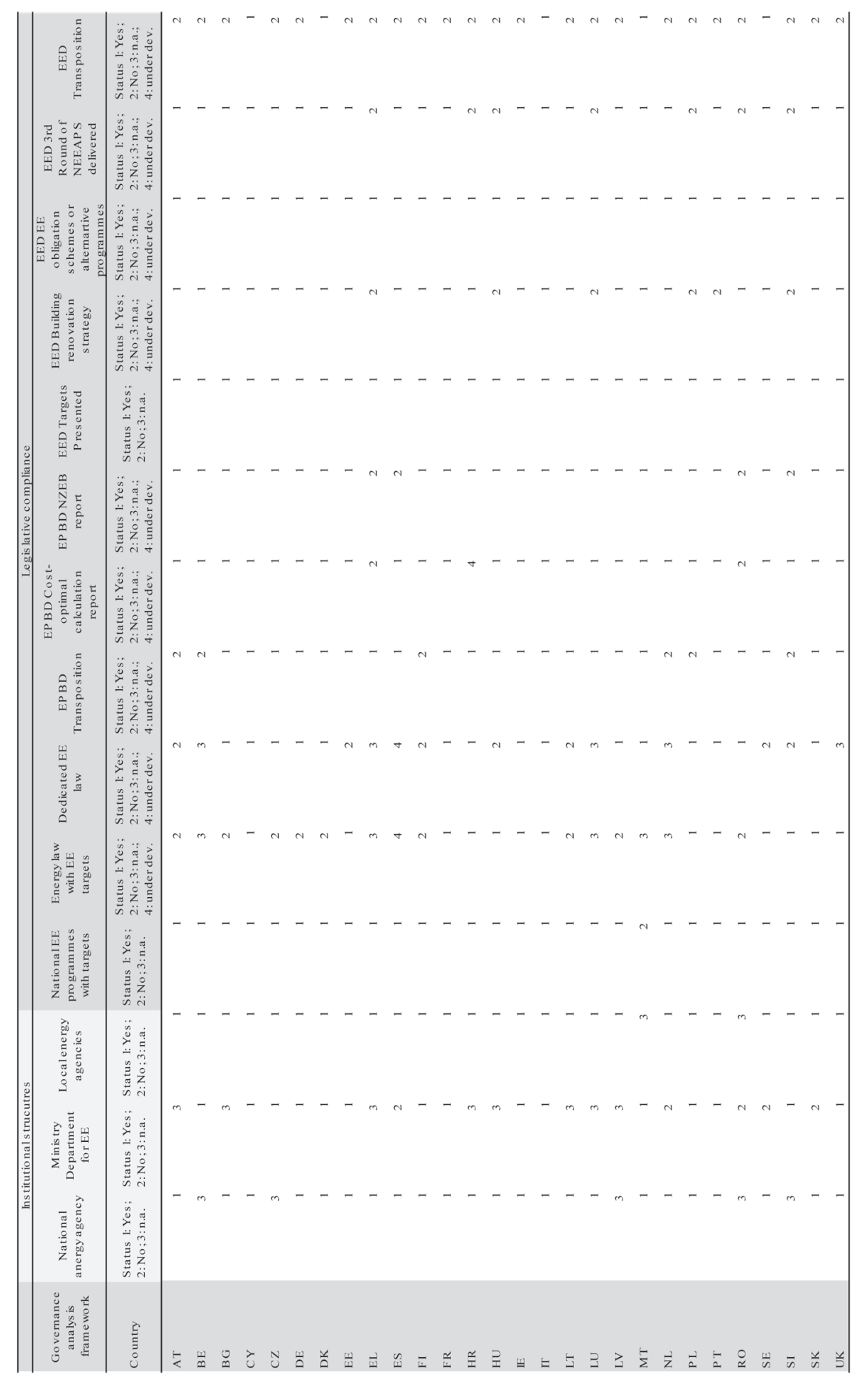


Série Investigação

Imprensa da Universidade de Coimbra

Coimbra University Press

2015

mais

Programa Operacional Regional do Centro

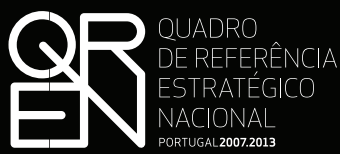

PORTUGAL 2007.2013

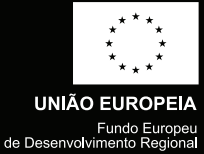

- $\mathbf{U}$

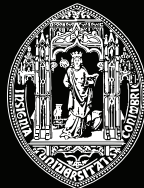

C •

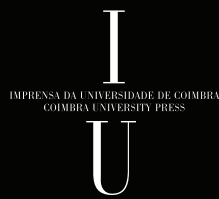

